Research Article

\title{
The effect of gender on environmental attitude: A meta-analysis study
}

\author{
Ahmet Gökmen \\ Gazi University, Gazi Faculty of Education, Turkey
}

\begin{abstract}
The present study aims to analyze the results of the studies conducted on determining the effect of gender on the environmental attitudes of individuals through the meta-analysis method. To this end, literature consisting of studies conducted between the years 2009-2019 was reviewed. A total of 257 publications related to the subject were collected in a pool. In line with the inclusion criteria determined, 53 of these studies suitable for the coding protocol were included in the study. The sample of the study consisted of 22,103 individuals (12,188 females and 9,915 males). Calculation of the effect size of the studies and analyses for heterogeneity and publication bias were performed using the Comprehensive Meta Analysis statistical program. A high level of heterogeneous distribution was determined in the studies included in the meta-analysis. Therefore, the general effect size value of the gender variable on the environmental attitudes of the individuals was obtained as $d=.28$ using the random effects model. The results showed that gender variable affected environmental attitude in favor of females at a low level. In addition, the moderator analyses indicated that this difference was based on the participants' educational level and the highest difference occurred at the primary education level. Considering the results, it is recommended to start environmental education at an early age.
\end{abstract}

Keywords: Environmental attitude; Meta-analysis; Gender; Attitude; Effect size

Article History: Submitted 12 December 2020; Revised 27 February 2021; Published online 17 March 2021

\section{Introduction}

In the period we live in, called as Anthropological era by some researchers (Crutzen, 2003; Steffen et al., 2007), many environmental problems such as air pollution, depletion of potable water resources, loss of biodiversity, and notably, climate changes have occurred (Gautier, 2014; Intergovernmental Panel on Climate Change [IPCC], 2013; Sonnenfeld \& Mol, 2002; World Wide Fund for Nature, 2018). Environmental pressure started with the establishment of agricultural societies by human beings reached high levels in the industrial era and has continued to increase today. Although the claim of some research that the environment is polluted even if humans do not exist (Akyüz, 2020) is partially true, effects of human are beyond pollution in that while doing activities harming the environment on the one hand, they damage the systems that provide self-renewal capacity of the environment on the other hand. An increase in single-use

Address of Corresponding Author

Ahmet Gökmen, PhD, Gazi University, Gazi Faculty of Education, Department of Biology Education, 06500, Ankara, Turkey.

$\triangle$ ahmetgokmenii@gmail.com

0000-0001-9268-7812

How to cite: Gökmen, A. (2021). The effect of gender on environmental attitude: A meta-analysis study. Journal of Pedagogical Research, 5(1), 243-257. http://dx.doi.org/10.33902/JPR.2021167799 
plastic products was determined sometime after the emergence of the global COVID-19 Pandemic (Silva et al., 2020); however, reports stating that air pollution decreased even after a short period of inactivity were published (National Aeronautics and Space Administration, 2020; European Space Agency, 2020). Therefore, a significant part of the environmental problems experienced today is human-induced (Çoban, 2014; Williams \& Cary, 2002), but the solution is based on people's awareness regarding the root of the problem (Rickinson, 2001).

Environmental education is the best way to raise awareness of people about the environment. It is the process of learning necessary information about the environment, forming positive attitudes toward the environment, developing the right behaviors, and creating conscious societies that act with lifelong awareness in every point of life (Erol \& Gezer, 2006; Gülersoy et al., 2020). Well-planned environmental education that includes practical activities plays an important role in providing individuals with exemplary behaviors toward the environment.

Knowing environmental issues enables individuals to predict the results of their activities. For example, an individual who knows ecological relationships in nature can predict what kind of impasse the other related species, and perhaps the whole ecosystem, could face if any species becomes extinct and can, therefore, shape their behavior accordingly. However, many studies emphasize that positive feelings and attitudes are more important than providing information to individuals in environmental education. Pooley and O'Connor (2000) and Iozzi (1989) state that environmental attitudes are directly related to behaviors and knowledge lags behind them. For this reason, the concept of attitude toward the environment becomes important as one of the determining factors of behavior.

Attitudes that are formed as a result of individuals' perceptions and prepares the ground for their behaviors (Akande, 2009; Kağıtçıbaşı, 2010) are the positive and negative emotions that are organized based on any subject, concept, object, phenomenon or event, motivation and information related to that subject (Güney, 2000; Kağıtçıbaşı, 2010; Tezbaşaran, 1996). Ajzen and Fishbein (1977) state that attitudes consist of four elements: action, goal-oriented action, actionoriented content, and time. Erten (2005) defines environmental attitude as "individuals' emotions such as fear, anxiety, anger caused by environmental problems, their value judgments about the environment, and their attitudes and thoughts that can be positive or negative, such as taking part in solving environmental problems." In this regard, attitudes toward the environment directly affect the perspectives and preferences of individuals regarding environmental events.

However, it is not easy to change attitudes in a short time, and a long and stable process is needed to build positive attitudes (Ekici et al., 2014). Since attitudes, in a general sense, can be gained more easily in childhood, environmental education studies should start at an early age. Dewey (1996) states that education given at early ages is very important for building awareness, creating desired behavior, and enhancing positive attitudes towards the environment.

Güven (2013) emphasizes that individuals with a positive environmental attitude exhibit positive behaviors towards the environment, and that determining the level of attitudes of individuals towards the environment and environmental problems and taking necessary measures in line with results are of great importance in terms of eliminating and preventing environmental problems. Individuals with negative attitudes towards the environment do not react to environmental problems and even can become a part of the problems (Uluçınar Sağır et al., 2008). Therefore, it is very valuable for individuals of all ages, genders, professions, and socio-economic backgrounds to have a positive environmental attitude.

The environmental education issue in Turkey has attracted the attention of researchers due to the integration of related subjects into the curricula after the 2000s and the intensive perception of environmental issues. After this process, studies on this issue have gradually increased. In the relevant literature reviews conducted within the framework of the inclusion criteria determined for this study, 257 studies on environmental attitude were encountered. However, studies evaluating these studies as a whole are limited in number. 
Among these studies, Güven et al. (2014), in their studies presenting a general perspective to the relevant literature, tried to reveal the current situation by examining the studies with environmental education as a research subject in a four-year period, between 2007 and 2011, through content analysis. They evaluated 112 studies according to the classification criteria such as publication year, language, participant, research type, research area, data collection tool and data analysis program. According to the results, the researchers determined that $78 \%$ of the studies were published in Turkish and most of them aimed the higher education level. They revealed that the studies were mostly related to the affective domain and quantitative research methods were generally used by researchers of these studies. Özbey and Şama (2017) examined 65 graduate dissertations in their study to determine the general orientations in master's theses and doctoral dissertations on environmental education published between 2012 and 2016. It was found in those studies that the participant groups mostly consisted of primary and secondary school students, and attitudes towards the environment and environmental problems was most studied. Yilmaz et al. (2015) studied master's theses and doctoral dissertations on environmental education published between the years of 1992 and 2011 in Turkey. In their study, they examined 178 studies and reported that higher education and primary education students were included as the participant group, and more emphasis was placed by theses studies on attitude toward the environment, environmental awareness, and environmental knowledge. These descriptive studies show that there has been a considerable number of studies on attitudes toward the environment, which is an important issue. However, the results of the studies were not sufficiently addressed in these studies, and dependent and independent variables and their relations with environmental attitude were not mentioned.

Gökçe and Sarıyar (2019) conducted a descriptive study on why female and male students' attitudes toward the environment are different. In their study, the researchers tried to determine why attitudes toward the environment differ in favor of female students. Using a qualitative research approach, they interviewed five parents with sons and daughters and five social studies teachers. At the end of their study, the researchers found that the reasons for female students to have higher attitudes towards the environment than male students were based on gender roles, emotional and physiological characteristics, traditions, family, and environmental factors.

The present meta-analysis study aims to determine the effect of gender on environmental attitude by synthesizing the statistical results of the studies conducted in Turkey on environmental attitude. As a result of reviewing the related literature, no meta-analysis study carried out in Turkey on environmental attitude has been encountered. Accordingly, there is no meta-analysis study revealing the effect of gender on environmental attitude. In this respect, the study data is thought to contribute to the literature.

\section{Method}

\subsection{Research Design}

In this study, a meta-analysis of studies conducted in Turkey was carried out to determine the effect of gender on attitudes toward the environment. Meta-analysis is the process of reaching a general conclusion by synthesizing the statistical results of independent studies on a particular subject. Meta-analysis studies aim to reveal the facts about a subject by combining the findings obtained from studies conducted in different places and times on the same subject and to reach the most accurate result quantitatively by increasing the number of samples (Cumming, 2012; Ellis, 2012; Petticrew \& Roberts, 2006).

\subsection{Data Collection}

In the present study, studies employing different scales to measure individuals' attitudes toward the environment in Turkey were considered as the main data source. Accordingly, master's theses and doctoral dissertations, articles and reports on environmental attitude published between 2009 and 2019 were reached to collect the data. To find the studies, "environment ("çevre" in Turkish) 
and attitude ("tutum" in Turkish) keywords were used; theses and dissertations were searched in the national thesis center of Turkish Council of Higher Education (Yüksek Öğretim Kurulu [YÖK]) and articles were examined in TR Index databases. Also, some studies on environmental attitudes formulated the focus keywords of the present study, environment and attitude, as "attitudes towards environmental problems" and were, in essence, similar to those including the focus keywords. In line with the opinions of field and field education experts, such studies were, therefore, included in the meta-analysis. As a result, 257 studies on attitude toward the environment in five different education levels - primary education, secondary school, high school, university, and other different age and occupational groups - were found. Some of these studies were excluded from the analysis as they did not meet the inclusion criteria of the study.

\subsubsection{Inclusion criteria}

The criteria used for the selection of the studies to include in the analysis within the scope of the study are as follows:

1. The study should be conducted within the borders of Turkey,

2. The study should be published between 2009 and 2019,

3. The study should be published on the National Thesis Center's unpublished master's theses or doctoral dissertations page or in national and refereed journals in National Academic Network and Information Center (TR Index),

4. The study should report the effect of gender on environmental attitude,

5. The study should report the validity and reliability of data collection tools used to measure environmental attitude,

6. To calculate the standardized effect size, the studies should be empirical, the sample sizes of the gender groups and the mean, standard deviation values should be presented in the study.

Since the effect of gender on environmental attitude is under focus in this study, review articles and qualitative studies that failed to meet some of the abovementioned criteria were not included in the analysis. Of the 257 studies examined according to the gender variable, 110 were not included since they were theoretical, 30 were not suitable for the sample group, and 64 did not provide the arithmetic mean and standard deviation values or the values required to calculate them.

Following the collection of the studies measuring the attitude toward the environment, the coding phase was carried out in detail and detailed information about the studies was presented. Researchers should create a clear and detailed coding system as much as possible regarding the studies included in a meta-analysis (Petticrew \& Roberts, 2006). Accordingly, in the coding system created for the studies included by the present meta-analysis, the identification number of the study, title, names of the author or authors, and publication year and type were entered first. Then, the number, mean, standard deviation of the sample in the studies, the number of samples for males and females, mean and standard deviation values were entered. The codings were made separately by the researcher and two experts, then they gathered together for comparison. In this way, it was tried to prevent material errors during the data entry phase. In addition, a meeting was held by the researchers and experts supporting the study to discuss the exclusion of the studies that did not meet the inclusion criteria.

Validity of the general effect size in a meta-analysis depends on the validity and reliability of the studies included in the analysis (Petitti, 2000). Therefore, the validity and reliability reports of the attitude scales in the studies in this meta-analysis were checked and it was observed that their validity had been ensured. The general characteristics of the studies that meet the inclusion criteria and were used for the present meta-analysis are shown in Table 1. 
Table 1

The general characteristics of the studies included in the meta-analysis

\begin{tabular}{llrr}
\hline Variable & Category & $f$ & $\%$ \\
\hline \multirow{5}{*}{ Publication year } & 2009 & 3 & 5.7 \\
& 2010 & 5 & 9.4 \\
& 2011 & 5 & 9.4 \\
& 2012 & 7 & 13.2 \\
& 2013 & 8 & 15.0 \\
& 2014 & 5 & 9.4 \\
& 2015 & 7 & 13.2 \\
& 2016 & 6 & 11.3 \\
& 2017 & 4 & 7.5 \\
& 2018 & 2 & 3.8 \\
\multirow{2}{*}{ Publication types } & 2019 & 1 & 1.9 \\
\hline \multirow{3}{*}{ Education levels } & Articles & 28 & 52.8 \\
& Theses & 25 & 47.2 \\
\hline & Primary education & 11 & 20.8 \\
& Secondary school & 12 & 22.6 \\
& High school & 2 & 3.8 \\
& Universities & 22 & 41.5 \\
& Other fields & 6 & 11.3 \\
\hline
\end{tabular}

As shown in Table 1, when the publication year of 53 studies included in the meta-analysis was considered, most of the studies (eight, [15.0\%)] were conducted in 2013 and the least studies belonged to 2019 with one study (1.9\%). Of the studies, $28(52.8 \%)$ were articles, $25(47.2 \%)$ were theses. Considering the education levels where the studies were carried out, 11 studies (20.8\%) were at the primary education, 12 studies $(22.6 \%)$ were at the secondary school, two studies (3.8\%) were in high school, 22 studies (41.5\%) were at universities and six studies $(11.3 \%)$ were in other fields. In addition, when the sample sizes in the studies were calculated, the total sample size in the meta-analysis was 22103, 12,188 females (55\%) and 9,915 males (45\%).

\subsection{Data Analysis}

As the first step, the effect size for each study was calculated by using the quantitative data of the studies in the meta-analysis. Effect size is a standard measure that is used to determine the strength and direction of the relationship in a study (Başol-Göçmen, 2004). Although there are different effect sizes, Hedges' g coefficient was used in this study because studies had mean scores that are obtained using different scales. In cases where the arithmetic mean values of the independent variables were not received from the same scales, the standardized arithmetic mean difference effect size method was used. "Hedges' g" statistics is the effect size defining the differences between the standardized means. This effect size shows how many standard deviations the means diverge from each other (Borenstein et al., 2013).

Various classifications are used in the interpretation of the effect size. One of these classifications is the one belonging to Thalheimer and Cook (2002), according to which the effect size is interpreted as insignificant if it is between -.15 and .15, small if between .15 and .40 , medium if between .40 and .75, large if between .75 and 1.10, very large if between 1.10 and 1.45, and enormous if more than 1.45. "Hedges' g" was used in the calculation of the effect size in this study, and Thalheimer and Cook's (2002) classification, which is a more comprehensive range, was chosen for the classification. Comprehensive Meta Analysis (CMA) statistical package program was used to calculate and compare effect sizes in the studies (Borenstein et al., 2013). In addition to 
these calculations, all other statistical operations related to meta-analysis have been done using this program.

In meta-analyses, two models, fixed and random, are used to calculate the effect size for each study. In the fixed effect model, each study in the meta-analysis is assumed to be obtained from a single population, and all studies are considered to have a single overall effect size. The fixed effect model is based on the assumption of homogeneity and it is accepted that there is no variance between studies. On the other hand, the random effects model assumes the variance both within and between studies (Thompson \& Sharp, 1999). Homogeneity test is usually performed to decide which of the two models to use in studies. The method frequently used for testing homogeneity is $\mathrm{Q}$ statistics. In the $\mathrm{Q}$ test, the null hypothesis claiming that all studies in the analysis share a common effect size is tested with the chi-square distribution (Borenstein et al., 2013). The acceptance of the null hypothesis shows that homogeneity is achieved and in case of homogeneity, the fixed effect model is used. However, the $Q$ statistics is affected by the number of studies in the analysis. For this reason, it should not be decided which model to use just based on the $Q$ value. In addition to the $\mathrm{Q}$ statistics, $I^{2}$ value is also used as a measure of heterogeneity, which is not affected by the number of studies. An $I^{2}$ value of $25 \%$ is interpreted as low, $50 \%$ as medium, and $75 \%$ as high heterogeneity (Cooper et al., 2009). Since the $Q$ statistics were found to be significant, the effect of the moderators was also examined. In case of heterogeneity, moderators are independent variables used in meta-analysis thought to explain this heterogeneity (Card, 2012). In this study, the variables, publication type (article, thesis) and education level (primary education, secondary school, high school, and university and other) were used as moderators.

For studies included in meta-analysis, publication bias is checked first. Publication bias is the overestimation of the average effect size due to the higher probability of publication of studies with large samples or studies with statistically significant results. Funnel plots and Orwin's Safe N calculation, Egger test and Begg Mazumdar Rank Correlation were used in the study to test whether there was a publication bias. The fact that the Egger test and the Begg Mazumdar Rank correlation are insignificant indicates that there is no publication bias. In the funnel plot, in cases where there is no publication bias, the effect size of the studies is spread symmetrically around the overall effect size since the sampling error is random (Borenstein et al., 2013). In case of publication bias, a skewed and asymmetrical distribution is expected (Üstün \& Eryılmaz, 2014).

\section{Results}

The meta-analysis study was conducted in the order described in the analysis part of the data. In line with this, it was first examined whether there was a publication bias in the studies included in the present meta-analysis. The funnel scatter plot of the effect sizes of the studies on the effect of gender on environmental attitude is shown in Figure 1.

In the funnel scatter plot in Figure 1, the standard error values of the studies are shown in the Y-axis, while the standardized average difference sizes of the studies are shown on the X-axis. Studies with small standard error values are located in the upper part of the funnel shape and near the average effect size. When the figure is examined, the majority of the studies included in the study are at the top of the funnel shape and close to the average effect size. In order to avoid publication bias in meta-analysis, it is expected that the studies will spread symmetrically on both sides of the vertical line showing the combined effect size (Borenstein et. al., 2013). According to this, based on the standard errors of the effect sizes of the studies examining the effect of gender on environmental attitude, six of the 53 studies in total are under the funnel scatter plot. On the other hand, the fact that most of the studies are symmetrically located at the top of the funnel plot shows that there is no publication bias. 
Figure 1

Funnel scatter plot for publication bias

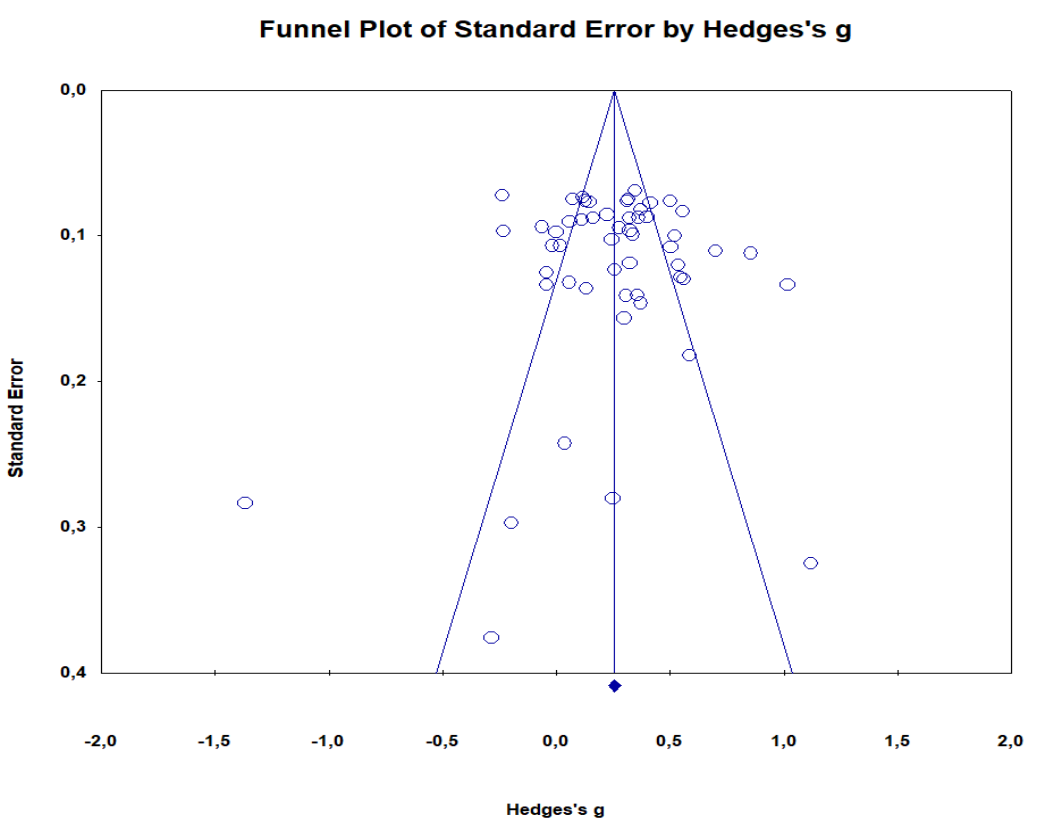

In addition to the funnel plot, Orwin Safe N Count, Duval and Tweedie's trim-fill method and Egger test were also used to examine whether there was a publication bias in the studies included in the study. The results obtained from these methods used are shown in Table 2.

Table 2

Publication Bias Test Results for the Effect of Gender on Environmental Attitude

\begin{tabular}{lllc}
\hline $\begin{array}{l}\text { Orvin Protected } N \\
\text { Number }\end{array}$ & \multicolumn{2}{c}{ Begg and Mazumdar rank correlation } & Egger Test \\
\hline $\begin{array}{l}\text { "trivial" Number of } \\
\text { studies required for } \\
\text { SOF }\end{array}$ & $\begin{array}{l}\text { Tau and } Z \\
\text { Values }\end{array}$ & $\begin{array}{l}\mathrm{p} \text { Value (double } \\
\text { tail) }\end{array}$ & p Value (double tail) \\
\hline 0.01 for 1298 & .02 and .25 & .80 & .87 \\
\hline
\end{tabular}

As can be seen in Table 2, the Orvin Protected N Number (Orwin failsafe N) shows how many more studies may not have been included in the meta-analysis, which can reduce the overall effect size calculated to the trivial level, considering the sample of the study. Such a number that is more than five to ten times the number of studies included in the analysis indicates no issue of publication bias for meta-analysis (Borenstein et al., 2013; Card, 2012). Orwin Protected N-number was found to be 1,298. This result means that 1,298 studies are needed for an average effect size of .26 to reach the level of .01 (trivial), which is almost zero effect. The present study consists of 53 studies conducted in Turkey, which are included on the basis of inclusion criteria obtained. There are not 1,298 studies published in Turkey on this issue, which can be considered as an indication of the lack of bias.

Begg and Mazumdar rank correlation and Egger test results, which are the other criteria for publication bias, were also examined. As a result of the Begg and Mazumdar rank correlation tests $(\mathrm{t}=.02 ; \mathrm{z}=.25 ; \mathrm{p}=.80>.05)$, it can be stated that there is no bias. The Egger test determines whether a possible asymmetry exists by testing it in the funnel plot. The fact that the Egger test is not significant can also show that there is no publication bias (Card, 2012). The result of the Egger test was found to be $p=.80$. This is another indication that there is no publication bias.

Before calculating the effect size of the study, a homogeneity test was performed. Determining the homogeneity shows which model to be used in calculating the effect size. A $Q$ test was 
performed for homogeneity first, and then the $I^{2}$ value was calculated as a complement to the $\mathrm{Q}$ statistics. The results obtained for both the $\mathrm{Q}$ test and the $I^{2}$ value are shown in Table 3.

Table 3

Findings of Homogeneity Test of Studies Based on Fixed Effects Model

\begin{tabular}{lccc}
\hline Homogeneity Value $(Q)$ & $d f(Q)$ & $p$ & $I^{2}$ \\
\hline 331.644 & 52 & 0.000 & 84.32
\end{tabular}

The $\mathrm{Q}$ statistics showing the homogeneity test was calculated as $\mathrm{Q}=331.644$. The $\mathrm{Q}$ value is greater than (67.50), which is 52 degrees of freedom chi-square $\left(\chi^{2}\right)$ value at the $95 \%$ significance level. According to this result, the hypothesis for absence of homogeneity was rejected in the fixed effects model. In other words, the distribution of effect sizes has a heterogeneous feature. Since the homogeneity test affected by the number of studies was higher than expected, the variance of the random effect component was calculated and the random effects model was used instead of the fixed effects model.

Since the $Q$ statistics are affected by the number of studies, the $I^{2}$ value was also calculated as a complement. The $I^{2}$ value shows the ratio of the total variance to the effect size. An $I^{2}$ value of $25 \%$ indicates low level of heterogeneity, $50 \%$ indicates moderate heterogeneity, and $75 \%$ indicates a high level of heterogeneity (Cooper et al., 2009). The average effect size $I^{2}$ value obtained for the gender variable according to the fixed effects model showed a high level of heterogeneity with $84 \%$. For this reason, random effects model was used instead of fixed effects model in the analyses. The results of the random effects model used to examine the effect of gender on environmental attitude are shown in Table 4.

Table 4

Findings Regarding Effect Size According to Random Effects Model

\begin{tabular}{ccccccc}
\hline \multicolumn{6}{c}{ Average effect size } & \multicolumn{5}{c}{ 95\% confidence interval } \\
\hline $\mathrm{g}$ & $\mathrm{n}$ & $\begin{array}{c}\text { Standard error } \\
\text { value }\end{array}$ & $\begin{array}{c}\text { Lower } \\
\text { limit }\end{array}$ & Upper limit & $\mathrm{Z}$ & $\mathrm{p}$ \\
\hline .26 & 53 & .04 & .18 & .33 & 7.08 & 0.000 \\
\hline
\end{tabular}

The results of the analyses made according to the random effects model in Table 4 reveal that the standard error value is .04, the lower limit of the $95 \%$ confidence interval is .18, the upper limit is .33, and the average effect size is .25 , which all indicate that females showed more positive attitudes in environmental attitude than males. The calculated effect size was considered to be small according to the classification made by Thalheimer and Cook (2002). The result of the $\mathrm{Z}$ test calculated for significance was found as $Z=7.08(\mathrm{p}<.01)$. According to this result, a small effect size was found in favor of female on environmental attitude. The forest plot showing the effect sizes of the studies included in the study is shown in Figure 2.

Figure 2 shows the forest plot of the effect sizes of the studies according to the random effects model. While the observed effect size of the studies is shown with black squares, the horizontal lines on both sides of each square show the $95 \%$ confidence interval of the effect size. The diamond shaped rhombus at the bottom of all squares shows the overall effect size obtained from all studies. When Figure 2 is examined, the effect sizes of most of the studies are positive, while the effect sizes of some studies are negative. The studies with positive effect size show results in favor of females in environmental attitude, whereas the studies with negative effect size show results in favor of males. 
Figure 2

The Forest Plot Showing the Effect Sizes of the Studies

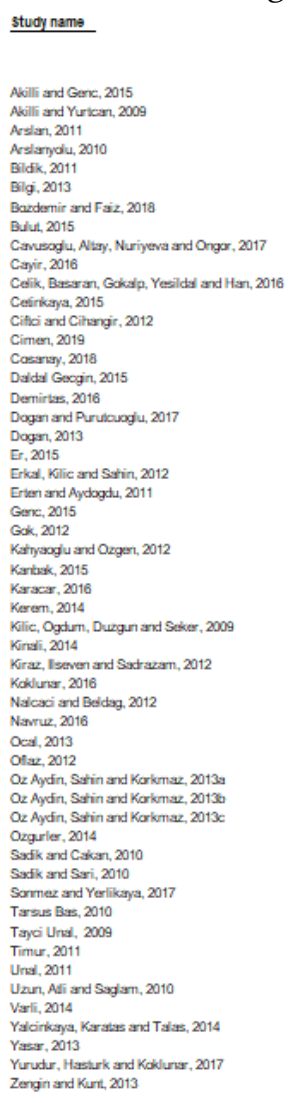

\begin{tabular}{|c|c|c|c|c|c|c|}
\hline \multirow[b]{2}{*}{$\begin{array}{l}\text { Hodges's } \\
g\end{array}$} & \multirow[b]{2}{*}{$\begin{array}{c}\text { standard } \\
\text { error }\end{array}$} & \multicolumn{3}{|c|}{ statistice for each study } & \multirow[b]{2}{*}{ z-Valus } & \multirow[b]{2}{*}{ p-Value } \\
\hline & & Varlances & $\begin{array}{c}\text { Lower } \\
\text { Iimit }\end{array}$ & $\begin{array}{l}\text { Upper } \\
\text { nimit }\end{array}$ & & \\
\hline 0.073 & 0.075 & 0,006 & $-0,074$ & 0.220 & 0.971 & 0,3031 \\
\hline 0.503 & 0,108 & 0.012 & 0.292 & 0.714 & 4.678 & 0.000 \\
\hline 0.856 & 0.112 & 0.013 & 0.636 & 1.076 & 7.635 & 0.000 \\
\hline 0,000 & 0,090 & 0.008 & -0.117 & 0.237 & 0.063 & 0.507 \\
\hline 0.038 & 0.242 & 0.059 & -0.438 & 0.513 & 0.155 & 0.877 \\
\hline 0.118 & 0.074 & 0.005 & -0.027 & 0.262 & 1.593 & 0.111 \\
\hline 0.311 & 0.078 & 0.006 & 0.162 & 0.480 & 4034 & 0.000 \\
\hline 0.111 & 0.099 & 0,008 & -0.063 & 0295 & 1248 & 0.212 \\
\hline 0.372 & 0.166 & 0.021 & 0.025 & 0.058 & 2544 & 0.011 \\
\hline 0.099 & 0.110 & 0.012 & 0.483 & 0.915 & 6.341 & 0,0 \\
\hline 0.144 & 0.077 & 0.006 & -0.007 & 0.295 & 1.874 & 0061 \\
\hline 0.298 & 0.157 & 0.025 & -0.009 & 0.805 & 1,903 & 0,057 \\
\hline 0.132 & 0.136 & 0.019 & $-0,136$ & 0.399 & 0,965 & 0,3304 \\
\hline 0.256 & 0.123 & 0.015 & 0.014 & 0,499 & 2074 & 0,038 \\
\hline 0.056 & 0.132 & 0.017 & -0.203 & 0.315 & 0.425 & 0.671 \\
\hline 0.325 & 0.119 & 0.014 & 0.091 & 0.550 & 2.729 & 0.006 \\
\hline 0,399 & 0,087 & 0,008 & 0.228 & 0.570 & 4,573 & 0,000 \\
\hline-0.041 & 0.125 & 0.016 & .0287 & 0.204 & -0399 & 0,742 \\
\hline 0.585 & 0,182 & 0.033 & 0.227 & 0.942 & 3207 & 0,001 \\
\hline 0.596 & 0,128 & 0.016 & 0.295 & 0,799 & 4.257 & 0,000 \\
\hline 0,357 & 0,141 & 0,020 & 0.031 & 0.633 & 2.538 & 0,011 \\
\hline 0.559 & 0,130 & 0.017 & 0,304 & 0.814 & 4,303 & 0,000 \\
\hline-0.064 & 0,094 & 0.009 & -0.248 & & & 0,496 \\
\hline 0,347 & 0,069 & 0.005 & 0.212 & 0,483 & 5.019 & 0,000 \\
\hline 0,413 & 0,077 & 0,006 & 0.262 & 0.565 & 5,345 & 0,000 \\
\hline 0,127 & 0.076 & 0,006 & $-0,022$ & 0.276 & 1,673 & 0,094 \\
\hline 0231 & 0097 & 0009 & 040 & 0.04 & 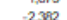 & 0010 \\
\hline 0.362 & 0.087 & 0,008 & 0,190 & 0.533 & 4,137 & 0,000 \\
\hline 0024 & 0000 & 0007 & 0.056 & 0.391 & 2617 & 0000 \\
\hline 0.324 & 0,097 & 0.009 & 0.135 & 0.513 & 3,356 & 0001 \\
\hline-0.196 & 0.297 & 0.008 & -0.778 & 0.307 & -0.658 & 0.510 \\
\hline-0.019 & 0,107 & 0.011 & -0.228 & 0.191 & $\begin{array}{l}-0,173 \\
\end{array}$ & 862 \\
\hline 0,335 & 0.099 & 0.010 & 0.141 & 0.529 & 3,300 & $\infty$ \\
\hline 0.244 & 0,103 & 0.011 & 0,042 & 0,406 & 2,373 & 0,018 \\
\hline 0.276 & 0.095 & 0.009 & 0.090 & 0.061 & 2914 & 0,00 \\
\hline 0249 & 0.250 & 0,079 & -0.300 & 0,798 & 0.880 & 0,375 \\
\hline 1,118 & 0.325 & 0,106 & 0,091 & 1.755 & 3442 & 0,00 \\
\hline-1396 & 0.284 & 0,090 & -1.922 & -0810 & -4815 & 0,00 \\
\hline-0295 & 0.376 & 0.141 & -1.022 & 0.452 & -0.758 & 0,48 \\
\hline 0,000 & 0,097 & 0.010 & -0.191 & 0,191 & 0,000 & 100 \\
\hline 0.308 & 0.141 & 0,020 & 0001 & 0.584 & 2182 & 090 \\
\hline 0.162 & 0.068 & 0.008 & 0011 & 0.334 & 1.800 & 000 \\
\hline 0.377 & 0.022 & 0.007 & 0210 & 0.597 & 4523 & 000 \\
\hline-0.236 & 0.073 & 0.005 & -0.378 & -0.094 & -3255 & 0,00 \\
\hline 0,520 & & 0010 & 0.324 & 0.716 & 52012 & 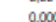 \\
\hline 03 & & & & 0,492 & 3651 & 00 \\
\hline 0.5 & & & & 0,72 & 4453 & 000 \\
\hline & & & 0,391 & 0.71 & 6.061 & 0,00 \\
\hline 0.5 & 0.076 & & 0.350 & 0.649 & 6.553 & 0,00 \\
\hline-0.04 & 0.1 & & -0.306 & 0.218 & -0.328 & 0.74 \\
\hline 10 & & 0.018 & 0756 & $12 \pi$ & 7.619 & 00 \\
\hline 0.0 & 0,107 & 0.011 & $-0,191$ & 0.228 & 0,173 & 63 \\
\hline 0.317 & 0.075 & 0.006 & 0,170 & 0,464 & 4230 & 0,000 \\
\hline 0.259 & 0.037 & 0.001 & 0.188 & 0.331 & 7.0289 & 0,000 \\
\hline
\end{tabular}

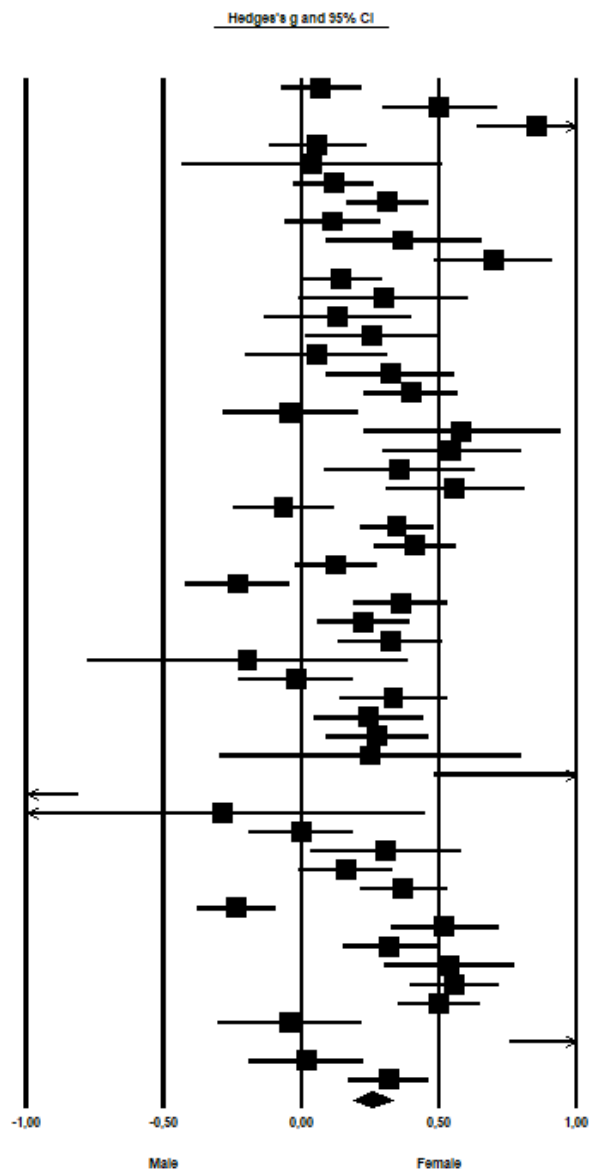

\subsection{Moderator Analyses}

According to the homogeneity test results, a moderator analysis was conducted to examine whether various moderator variables affected the relationship between gender and environmental attitudes and to find heterogeneity between the studies. Publication type and education level were considered as moderator variables. Moderator analyses results are shown in Table 5.

Table 5

Moderator Analyses Results for Environmental Attitude

\begin{tabular}{lccccccc}
\hline Moderator & $k$ & $g$ & $S E$ & $\% 95 C I$ & $Q_{b}$ & $p$ & $I^{2}$ \\
\hline Publication type & 53 & & & & & \\
\hline Article & 28 & .24 & .04 & $.15-.32$ & .45 & .501 \\
\hline Thesis & 25 & .29 & .06 & $.17-.41$ & & & \\
\hline Education level & 53 & & & & & & \\
\hline Primary education & 11 & .38 & .11 & $(.16)-(.60)$ & 9.72 & $.045^{*}$ & 92.51 \\
\hline Scondary school & 12 & .30 & .05 & $(.19)-(.41)$ & & & 75.44 \\
\hline High school & 2 & .33 & .22 & $(-.10)-(.77)$ & & & 92.45 \\
\hline Universities & 22 & .24 & .05 & $(.14)-(.33)$ & & & 74.61 \\
\hline Other fields & 6 & -.06 & .09 & $(-.19)-(.18)$ & & & 72.04 \\
\hline
\end{tabular}

${ }^{*} \mathrm{p}<.05 Q_{b}=\mathrm{Q}$ Value between the Groups 
The moderator effect of publication type and education level variables on effect sizes calculated by gender variable were examined. Publication type moderators were divided into two groups as article $(\mathrm{k}=28)$ and theses/dissertations $(\mathrm{k}=25)$. Effect sizes belonging to publication type groups were calculated as .24 for article type studies and .29 for thesis type studies. The variance between the studies was not significant for the publication type $(\mathrm{Q}=.45, \mathrm{p}=.501>.05)$, which showed that the publication type did not affect the effect size of the environmental attitude by gender.

The education level moderators were divided into five groups that are primary education $(k=11)$, secondary school $(k=12)$, high school $(k=2)$, university $(k=22)$, and other $(k=6)$. The effect sizes of the education level groups were calculated as .38 for studies on primary education, .30 for studies on secondary school, .33 for studies on high school, .24 for studies on universities, and -.06 for studies on the other category. The variance between these studies is significant in favor of the education level moderator variable $(\mathrm{Q}=9.72, p=.045<.05)$. The implementation of studies in different education levels has an impact on the effect size of the individuals' environmental attitude according to the gender variable. When the effect sizes of the education levels are compared, the highest effect size is found to be for primary education (.38) and the lowest effect size is for the other category (-.06).

\section{Discussion and Conclusion}

Attitude toward the environment has been the focus of many studies in which it is accepted as a determining factor in environmental behavior. These studies mostly consist of descriptive studies that reveal the current state of environmental attitude or experimental studies that test the effectiveness of learning methods.

In this study, which aims to determine the effect of gender on environmental attitude, 53 studies out of 257 in total were included within the framework of the determined inclusion criteria. Although 64 studies complied with the research criteria, arithmetic mean and standard deviation values or the values required to calculate them were not stated, so they were not included in the meta-analysis process. Similarly, Dikmen and Tuncer (2018) reported the same situation in the graduate theses/dissertations and articles they examined regarding Computer-Aided Instruction, and stated that there was no standard in the presentation of the data of the research and there were deficiencies in the findings of some studies.

Studies that investigated environmental attitudes by gender reported different results. For example, Ak1llı and Yurtcan (2009) in their study found that female preservice teachers, compared to male preservice teachers, have more positive attitudes towards the environment. In a different study by Çetinkaya (2015), environmental attitudes of individuals who participated in outdoor sports. It was similarly found that females, compared to males, have more positive attitudes. Studies by Bozdemir and Faiz (2018) and Çavuşoğlu et al., (2017) investigated primary school students' attitudes towards the environment. These studies also found that female students, compared to their male peers, have higher scores on environmental attitudes. However, some studies put forward contradicting results to those reported by the aforementioned studies. Some studies showed no difference in environmental attitudes by gender. For example, Akıllı and Genç (2015) in their study with secondary school students found that environmental attitudes do not vary by gender. Similarly, Yalçınkaya et al. (2014) in their study with preservice teachers also found no difference between male and female preservice teachers in terms of their environmental attitudes. In some studies, albeit in a small number, it was determined that males have more positive environmental attitudes than females. Karaçar (2016) reported that males who engaged in recreational activities, compared to females, have more positive environmental attitudes.

For the studies included in the present study, it was checked whether there was a publication bias. To do this, Orwin Safe N Count, Duval and Tweedie's trim-fill method and Egger test were used and funnel plot was also benefited. The results obtained from the funnel plot and other statistical tests showed that there was no publication bias for the meta-analysis. Homogeneity tests were carried out to decide whether the fixed or random effects model should be used to calculate 
the overall effect size in the study. As a result of homogeneity tests, random effects model was used due to the heterogeneity among the studies. According to the results obtained, the effect size of gender on environmental attitude was determined as .26. This result reveals that gender has a low level of effect on environmental attitude in favor of women. Gökçe and Sarıyar (2019) explained the reasons for female students to have a more positive attitude toward the environment than males under four different themes in their study: family, environmental factors, gender roles, and emotional and physiological characteristics. Females generally have more developed abilities of pity, responsibility and empathy than males (Beutel \& Marini, 1995), which affects their sensitivity to the environment and environmental problems.

The gender-environment relationship between publication type or education level of the participant group of the studies was determined with the moderator analyses. According to the results, publication type, that is, whether the study is an article or a thesis/dissertation, did not affect environmental attitudes according to the gender variable. There are certain differences between a thesis and article in terms of their intention, focus, integrity, and target audience (Paltridge, 2017; Staller, 2019). Nevertheless, their processes of reporting results are similar. Also, theses on Educational Sciences are generally similar to articles of the same field. Besides, master's students are generally less experienced than doctoral students and article writers. However, if they follow the right steps, they can achieve very successful results. The environmental attitude of gender is not expected to change according to the publication type moderator, since the studies included in the study were selected based on certain criteria beforehand.

However, environmental attitude studies at different education levels differed according to the gender variable. The biggest difference was observed in the primary education. This result can be interpreted as that the effect of gender roles on environmental attitudes at younger ages is high and this difference decreases as the education levels increase. It is important to start environmental education at a young age. The results of the study indicate that an early start of environmental education is critical for children to develop a positive attitude toward the environment in the later stages of life and to raise them as responsible individuals (Grodzinska-Jurzcak et al., 2006; Turtle et al., 2015; Wilson, 1996).

\subsection{Suggestions}

Considering the results of the study, the following suggestions are made:

$>\quad$ The environmental attitudes of females are more positive than males. In this respect, it is recommended to combine environmental education with activities that will increase males' environmental attitudes and that are suitable for their physical and psychological structures. In that sense, recreation activities that include excitement and adventure can be planned and implemented, and their effects can be observed.

$>\quad$ The education level with the highest effect of gender on environmental attitude has been determined as the primary education. Students should be provided with practical activities that will improve their mental and physical health from an early age in touch with nature, and the relationships between environmental education and education programs should be strengthened.

$>\quad$ In most of the master's theses examined by the present study, some important statistical values or the information required to calculate these values were not included In this regard, it is recommended to provide training and support for graduate students at the institutes on statistical analyses.

$>\quad$ The present study investigated master's theses and doctoral dissertations that were included by the Council of Higher Education National Thesis Center articles that were included by the National Academic Network and Information Center database, which were all made between the years 2009 and 2019 in Tukey. Further studies can investigate other articles included by different indices and, in particular, make comparative analyses with results of studies made in different countries. 


\section{References}

(References marked with an "*” indicate studies included in the meta-analysis.)

Ajzen, I., \& Fishbein, M. (1977). Attitude-behavior relations: A theoretical analysis and review of empirical research. Psychological Bulletin, 84(5), 888.

Akande, S. O. (2009). Knowledge, perception, and attitudes of library personnel towards preservation of information resources in Nigerian Federal University Libraries. Library Philosophy and Practice (e-journal), $303,1-8$.

*Akıllı, M., \& Genç, M. (2015). Examination of middle school students' sub-dimensions of environmental literacy in terms of various variables. Sakarya University Journal of Education,5(2), 81-97. https://doi.org/10.19126/suje.87773

*Akıllı, M., \& Yurtcan, T. (2009). An Investigation of Prospective Science Teachers Attitudes Towards in Terms of Different Factors (Sample of Kazım Karabekir Education Faculty). Erzincan University Journal of Education Faculty, 11(2), 119-131.

Akyüz, E. (2020). Çevre sorunlarında bilinmeyen 100 bilimsel gerçek [100 unknown facts about environmental problems]. Astana.

*Arslan, S. (2011). The influence of environment education on critical thinking and environmental attitude (Sakarya example) [Unpublished master's thesis]. Sakarya University.

*Arslanyolu, K. (2010). Investigation of elementary education student's attitudes towards environment according to multiple intelligence theory [Unpublished master's thesis]. Erzincan University.

Başol-Göçmen, G. (2004). Meta-analizin genel bir değerlendirmesi [An overview of the meta-analysis.] Sakarya University Journal of Education, 7,186-192.

Beutel, A. M., \& Marini, M. M. (1995). Gender and values. American sociological review, 436-448. https://doi.org/10.2307/2096423

*Bildik, G. (2011). The influence of enviroment unit in the 7th grade on students tititude toward enviroment and their environment knowledge [Unpublished master's thesis]. Gazi University.

*Bilgi, M. (2013). Developing and analysing a scale about attitudes of student teachers towards environmental challenges. Firat Üniversitesi Journal of Social Sciences, 23(2), 149-161.

Borenstein, M., Hedges, L., Higgins, J., \& Rothstein, H. (2013). Comprehensive meta-analysis version 3. Biostat.

*Bozdemir, H., \& Faiz, M. (2018). Ecocentric, antropocentric and antipathetic attitudes of teacher candidates towards the environment. Sakarya University Journal of Education,8(1), 61-75. https:// doi.org/10.19126/suje.330546

*Bulut, M. (2015). A study on determining the level of knowledge, attitude, environmental risk perception of secondary school students [Unpublished master's thesis]. Niğde University.

Card, N. A. (2012). Applied meta-analysis for social science research. The Guilford.

Cooper, H., Hedges, L. V., \& Valentine, J. C. (Eds.). (2009). The handbook of research synthesis and meta-analysis. Sage.

*Coşanay, B. (2018). Analysis of environmental attitudes of preschool children (five-six ages) in terms of child and teacher variables [Unpublished master's thesis]. İnönü University.

Crutzen, P. J., \& Steffen, W. (2003). How long have we been in the Anthropocene Era? Climate Change, 61, 251-257.

Cumming, G. (2012). Understanding the new statistics. Routledge, Taylor and Francis Group.

*Çavuşoğlu, F., Altay, B., Nuriyeva, G., \& Öngör, B. (2017). Analysis of environment knowledge and attitudes of the primary school students. Journal of Anatolia Nursing and Health Sciences, 20(4), 254-259.

*Çayır, Ş. (2016). A comparative study of the environmental attitudes and solution ideas for environmental issues of gifted students with those of their peers [Unpublished master's thesis]. Sakarya Universtiy.

*Çelik, S., Başaran T., Gökalp, M.R., Yeşildal M., \& Han O. (2016). Nursing Department and Medical Faculty students' attitudes towards environmental problems. Journal of Health Science and Profession, 3(2), 91-98.

*Çetinkaya, G. (2015). Are environmental attitudes affected by outdoor sports participation a study on university students. Spormetre Journal of Physical Education And Sport Sciences, 13(2), 137-142.

*Çiftçi, S., \& Cihangir, Ü. (2012). Primary school 4th and 5th grade scout lesson attitudes towards the environment. Journal of Values Education, 10(23), 49-64.

*Çimen, H. (2019). The investigation of science and classroom teacher candidates attitudes to sustainable environment [Unpublished master's thesis]. Gazi University.

Çoban, A. (2014). Doğa, toplum ve yöntem [Nature Society and Method]. In H. Reyhan, A. Mutlu, H. Doğan \& A. S. Reyhan (Eds.), Sosyal Çevre Bilimleri [Social Environmental Sciences.] (pp. 15-35). Siyasal. 
*Daldal Geçgin, N. (2015). The environmental perceptions of middle school students depending on their residential areas [Unpublished master's thesis]. Gazi University.

${ }^{*}$ Demirtaş, F. (2016). Exammation of the ecological footprint and sustainable environmental attitudes of eighth grade students in terms of different variables [Unpublished master's thesis]. Adıyaman University.

Dewey, J. (1996). Democracy and education (M. S. Otoran, Trans.). Başarı.

Dikmen, M., \& Tuncer, M. (2018). Bilgisayar destekli eğitimin öğrencilerin akademik başarıları üzerindeki etkisinin meta-analizi: Son 10 yılda yapılan çalışmaların incelenmesi [Meta-analysis of the effect of computer-assisted education on students' academic achievement: Examining the studies conducted in the last 10 years.] Turkish Journal of Computer and Mathematics Education, 9(1), 97-121. https://doi.org/10.16949/turkbilmat.334733

*Doğan, E. (2013). Knowledge levels and attitudes of prospective teachers and biologist candidates towards the environment. Elementary Education Online, 12(2), 413-424.

*Doğan, İ., \& Purutçuoğlu, E. (2017). The determination of the environmental awareness levels of social workers and their attitudes towards the environment. The Journal of Turkish Social Research, 21(2), 389-405.

Ekici, G., Gökmen, A., \& Kurt, H. (2014). Determining student teachers' cognitive structure on the concept of "computer". Gazi Üniversitesi Journal of Gazi Educational Faculty, 34(3), 357-401.

Ellis, P.D. (2012). The essential guide to effect sizes. Cambridge University Press.

*Er, F. (2015). Comparison of 8th grade students' attitudes towards the evironment in eco-schools and classical-schools and student views [Unpublished master's thesis]. Gazi University.

*Erkal, S., Kilic, I., \& Sahin, H. (2012). Comparison of environmental attitudes of university students determined via the new environmental paradigm scale according to the students' personal characteristics. Eurasian Journal of Educational Research, 49, 21-39.

Erol, G. H., \& Gezer, K. (2006). Sınıf öğretmenliğ̈ öğretmen adaylarına çevreye ve ç,evre sorunlarına yönelik tutumları [Attitudes of primary school teacher candidates towards environment and environmental problems]. International Journal of Environmental and Science Education, 1, 65-77.

Erten, S. (2005). Investigation of preservice preschool teachers' behaviors related to environmental awareness. Hacettepe University Journal of Education Faculty, 28, 91-100.

*Erten, S., \& Aydoğdu, C. (2011). The ecocentric, anthropocentric and antipathhetic attitudes toward environment in Turkish and Azerbaijani students. Hacettepe University Journal of Education, 41(41), 158169.

European Space Agency (ESA). (2020). Coronavirus lockdown leading to drop in pollution across Europe. https://www.esa.int/Applications/Observing_the_Earth/Copernicus/Sentinel5P/Coronavirus_lockdown_leading_to_drop_in_pollution_across_Europe

Gautier, C. (2014). Oil, water and climate (S. Genç, Trans.). TÜBİTAK.

*Genç, H. (2015). Investigating pre-school children's attitudes towards environment through multiple intelligences [Unpublished master's thesis]. Necmettin Erbakan University.

${ }^{*}$ Gök, E. (2012). A survey on elementaryschool students' environmental knowledge and environmental attitudes [Unpublished master's thesis]. Necmettin Erbakan University.

Gökçe, N., \& Sariyar, S. (2019). Reasons for the differentiation of the attitudes of female and male students towards the environment: teachers and parents opinions. The Western Anatolia Journal of Educational Sciences, 10(2), 131-145.

Grodzinska-Jurzcak, M., Stepska, A., Nieszporek, K., \& Bryda, G. (2006). Perception of environmental problems among pre-school children in Poland. International Research in Geographical and Environmental Education, 15(1), 62-76. https://doi.org/10.2167/irgee187.0

Gülersoy, A. E., Dülger, İ., Dursun, E., Ay, D., \& Duyal, D. (2020). What kind of environmental education? Some suggestions in the context of contemporary approaches. Electronic Turkish Studies, 15(5), 2357-2395. https://dx.doi.org/10.7827/TurkishStudies.44074

Güney, S. (2000). Davranış bilimleri [Behavioral sciences]. Nobel.

Güven, E. (2013). Development of environmental problems attitude scale and determination of teacher candidates' attitudes Gazi University Journal of Gazi Educational Faculty 33(2), 411-430.

Güven, E., Kaplan, Z., Varinlioğlu, S., Sungur, K., Gül, K. S., Hamalosmanoğlu, M., \& Bozkurt, O. (2014). Review of the studies about environmental education: Current status in Turkey. Necatibey Faculty of Education Electronic Journal of Science and Mathematics Education, 8(2), 1-18.

Intergovernmental Panel on Climate Change [IPCC]. (2013). Climate change 2013: The physical science basis. https://www.ipcc.ch/report/ar5/wg1/ 
Iozzi, L. A. (1989). What research says to the educator: part two: environmental education and the affective domain. The Journal of Environmental Education, 20(4), 6-13.

Kağıtçıbaşı, C. (2010). Günümüzde insan ve insanlar: Sosyal psikolojiye giriş [Man and people today: Introduction to social psychology]. Evrim.

*Kahyaoglu, M., \& Ozgen, N. (2012). An investigation of pre-service teachers' attitudes towards environmental problems in terms of several variables. Journal of Theoretical Educational Science, 5(2), 171185.

*Kanbak, A. (2015). Environmental attitudes and behaviors of college students: A case study conducted at a Kocaeli University. Kocaeli University Journal of Social Science Institute, 30, 77-90.

*Karaçar, E. (2016). The effect of attitudes towards environment and destination image on re-visit intention in recreational activities: Sample of Ilgaz Mountain National Park [Unpublished doctoral dissertation]. Gazi University.

*Kerem, Ö. (2014). A research about secondary school students' knowledge of the environment and their attitudes towards the enviroment (Example of the province of Çanakkale) [Unpublished master's thesis]. Çanakkale Onsekiz Mart University.

*Kılıç, N., Öğdüm, P., Düzgün, G., \& Şeker, S. (2009). First and senior class Adnan Menderes University student's attitudes, towards environmental problems. Kastamonu Education Journal, 17(1), 125-136.

*Kınalı, Ö. (2014). Determining adults' knowledge and attitudes towards environmental protection: The sample of Foça [Unpublished master's thesis]. Dokuz Eylül University.

*Kiraz, A., İlseven, S., \& Sadrazam, E. (2012). Assessment of environmental awareness and sensitivity of TRNC Republican Assembly members and staff. Eurasian Journal of Educational Research, 49, 229-242.

*Köklünar, S. (2016). The analyses of environmental attitudes of eighth grade primary school students [Unpublished master's thesis]. Gaziosmanpaşa University.

*Nalçacı, A., \& Beldağ, A . (2012). Identifying the environmental attitudes of 7th and 8th grade elementary students (Erzurum sample). Eastern Geographical Review, 17(28) , 141-154.

National Aeronautics and Space Administration (NASA). (2020). NASA probes environment, COVID-19 impacts, possible links. https://www.nasa.gov/feature/nasa-probes-environment-covid-19-impactspossible-links

*Navruz, C. (2016). Analysis of the environmental sensitivity of middle school students in rural areas (Erzincan Çayırlı district sample) [Unpublished master's thesis]. Erzincan University.

*Oflaz, V. (2012). Effects of project based learning on reservice science teachers' consciousnes towards environment and epistemological beliefs [Unpublished master's thesis]. Pamukkale University.

*Öcal, T. (2013). Determination of the attitudes of prospective social studies teachers towards environmental problems. International Journal of Geography and Geography Education, 27, 333-352.

${ }^{*} \mathrm{Öz}$ Aydın, S., Şahin, S., \& Korkmaz, T. (2013). Determination and comparison of elementary science, primary classroom and preschool teacher candidates' environmental attitude levels. Necatibey Faculty of Education Electronic Journal of Science and Mathematics Education, 2, 248-267. http://dx.doi.org/10.12973/nefmed209

Özbey, Ö. F., \& Şama, E. (2017). Investigation graduate environmental education in the context of theses published between the years 2012-2016. Bartin University Journal of Faculty of Education, 6(1), 212-226.

*Özgürler, S. (2014). Investigation of environmental literacy level and ecological footsprint of teacher candidates [Unpublished master's thesis]. Amasya University.

Paltridge, B. (2017). Publishing from a dissertation. A book or articles? J. McKinley \& H. Rose (Eds.), Doing research in applied linguistics: Realities, dilemmas and solutions (pp. 243-252). Routledge.

Petitti, D. B. (2000). Meta-analysis, decision analysis, and cost-effectiveness analysis: methods for quantitative synthesis in medicine. Oxford University Press.

Petticrew, M., \& Roberts, H. (2006). Systematic reviews in the social sciences. Blackwell Publishers.

Pooley, J. A., \& O'Connor, M. (2000). Environmental education and attitudes. Environment and Behavior, 32(5), 711-724.

Rickinson, M. (2001). Learners and learning in environmental education: A critical review of the evidence. Environmental Education, 7(3), 207-320.

*Sadık, F., \& Çakan, H . (2010). The environmental knowledge and attitude levels of the students of the biology department towards environmental problems. Çukurova University Journal of Social Sciences Institute, 19(1), 351-365.

*Sadık, F., \& Sarı, M. (2010). Student teachers'attıtudes towards environmental problems and their level of environmental knowledge. Cukurova University Faculty of Education Journal, 39, 129-141. 
Silva, A. L. P., Prata, J. C., Walker, T. R., Duarte, A. C., Ouyang, W., Barcelò, D., \& Rocha-Santos, T. (2020). Increased plastic pollution due to COVID-19 pandemic: Challenges and recommendations. Chemical Engineering Journal, 126683. https:/ / doi.org/10.1016/j.cej.2020.126683

Sonnenfeld, D. A., \& Mol, A. P. (2002). Globalization and the transformation of environmental governance. American Behavioral Scientist, 45(9), 1318-1339.

*Sönmez, E., \& Yerlikaya, Z. (2017). A field study on environmental knowledge levels and environmental attitudes of secondary education students: The case of Kastamonu city. Kastamonu Educational Journal, 25(3), 1239-1249.

Staller, K. M. (2019). From Dissertation to published article: Advice from an editor. Qualitative Social Work, 18(6), 897-904. https:// doi.org/10.1177/1473325019882791

Steffen, W., Crutzen, P. J., \& McNeill, J. R. (2007). The Anthropocene: are humans now overwhelming the great forces of nature. AMBIO: A Journal of the Human Environment, 36(8), 614-621. https://doi.org/10.1579/0044-7447

*Tarsus Baş, M. (2010). Evaluation of environmental attitudes of elementary school students [Unpublished master's thesis]. Middle East Technical University.

*Tayc1 Ünal, F. (2009). A study on the level of determination of the primery students' environmental behaviour, knowledge, consciousness and active participitation in Çorlu [Unpublished master's thesis]. Namik Kemal University.

Tezbaşaran, A. (1996). Likert tipi ölçek geliştirme kılavuzu [Likert type scale development guide.]. Turkish Psychology Association.

Thalheimer, W., \& Cook, S. (2002). How to calculate effect sizes from published research articles: A simplified methodology. http://education.gsu.edu/coshima/EPRS8530/Effect_Sizes_pdf4.pdf

Thompson, S. G., \& Sharp, S. J. (1999). Explaining heterogeneity in meta-analysis: a comparison of methods. Statistics in Medicine, 18(20), 2693-2708.

*Timur, S. (2011). Determining environmental literacy levels of preservice science teachers [Unpublished doctoral dissertation]. Gazi University.

Turtle, C., Convery, I., \& Convery, K. (2015). Forest schools and environmental attitudes: A case study of children aged 8-11 years. Cogent Education, 2(1), 1100103.

Uluçınar Sağır, Ş., Aslan, O., \& Cansaran, A. (2008). The examination of elementary school students' environmental knowledge and environmental attitudes with respect to the different variables. Elementary Education Online, 7(2), 496-511.

*Uzun, N., Atlı, K., \& Sağlam, N., (2010). Evaluation of the high school students' environmental attitudes and interest levels: Kalecik-Turkey Sample. Eurasian Journal of Educational Research, 10(41), 165-181.

*Ünal, S. (2011). Investigation of primary education second grade students' attitudes towards environment in terms of various variables (Karabük City case) [Unpublished master's thesis]. Balıkesir University.

Üstün, U., \& Eryılmaz, A. (2014). A research methodology to conduct effective research syntheses: Metaanalysis. Education and Science, 39(174), 1-32.

*Varll, D. (2014). Research on the attitute of 8th grade students in secondary schools toward environment [Unpublished master's thesis]. Gaziosmanpaşa University.

Williams, K. J., \& Cary, J. (2002). Landscape preferences, ecological quality, and biodiversity protection. Environment and Behavior, 34(2), 257-274. https://doi.org/10.1177/0013916502034002006

Wilson, R. A. (1996). Starting early: Environmental education during the early childhood years. Journal of Wildlife Rehabilitation, 23(2), 23-25.

World Wide Fund for Nature. (2018). Living planet report. https://www.worldwildlife.org/pages/livingplanet-report-2018

*Yalçınkaya, E., Karataş, A., \& Talas, M. (2014). A study on the environmental attitudes of candidate teachers. Mediterranean Journal of Humanities, 4(1), 275-284.

*Yaşar, Z. (2013). Primary education II. examining the knowledge, attitudes and behaviors of level students towards the environment in terms of science achievement [Unpublished master's thesis]. Gazi University.

Yılmaz, Ş., Aydın, F., \& Bahar, M. (2015). Identifying the general tendencies in the master's and doctoral theses concerning environmental education which were published between 1992- 2011. Adiyaman University Journal of Social Sciences, 19, 383-413. https://doi.org/10.14520/adyusbd.33216

*Yürüdür, E., Hastürk, H. G., \& Köklünar, S. (2017). The analyses of environmental attitudes of eighth grade primary school students. Journal of History School, 10(29), 447-466. http:/ / dx.doi.org/10.14225/Joh1041

*Zengin, U., \& Kunt, H. (2013). An analysis of secondary school students' attitudes towards trees and environment. Mustafa Kemal University Journal of Social Sciences Institute, 10(23), 155-165. 